\title{
Surabaya City Workers, Why Choose an Accountant Career?
}

\author{
${ }^{1}$ Hendra Dwi Prasetyo, ${ }^{2}$ Wulandari Harjanti, ${ }^{3}$ Kusuma Adi Rahardjo, ${ }^{4}$ Iman Supriadi
}

STIE Mahardhika Surabaya

\begin{abstract}
Careers are important for the lives of everyone, especially those of productive age. When someone chooses a career, it is an important matter in the life they lead. Because when someone chooses a career he also chooses to take real steps in fulfilling his life goals. Same with workers who determine their careers. They choose a career according to their abilities, interests and needs. Different abilities, interests and needs of a person. This study uses survey methods with quantitative data to find out why choosing an accountant's career. The population of this study is workers who are in the city of Surabaya, this is based on the objectives and objects of research conducted by researchers. While the sample of this research is workers who take accounting courses in the city of Surabaya. In this study the results of the analysis of the factors formed by 3 variables used as factors in the selection of accountants' careers are financial rewards, professional recognition and social values. The factor that shows the dominant value in choosing an accountant's career is financial rewards.
\end{abstract}

Keywords: financial rewards, professional recognition, social values and career selection of accountants.

\section{Introduction}

Growth in the level of education in Indonesia is now starting to increase; this is stated by the number of companies or large and small industries operating in the Indonesian region. The company requires job seekers to prepare themselves with the demands of the workforce. The high demands of companies in the world of work are also stated by the level of welfare of workers. Having a promising career is everyone's dream and hope (Yusran, 2017).

Careers are important for the lives of everyone, especially those of productive age. When someone chooses a career it is an important matter in the life they lead. Because when someone chooses a career he also chooses to take real steps in fulfilling his life goals. Same with workers who determine their careers. They choose a career according to their abilities, interests and needs. Different abilities, interests and needs of a person. It is undeniable that many undergraduate graduates also glance at other careers that are not in accordance with the chosen study program while in college. This is experienced by many accounting graduates who do not choose a career as an accountant (Ardianto, 2014).

Research conducted by Yusran (2017)shows that the factors of financial rewards, professional training and professional recognition influence the career selection of accountants / non-accountants. Research conducted by Umar (2014) shows that there is a relationship between personal interests, parental influence, future prospects, prestige, salary and career choice of accountants among Nigerian University students. Research conducted by Djuri, Said and Amiruddin (2019) shows that lifestyle, work environment, career path and money-oriented influence the selection of the accounting profession. Research conducted by Arnita, et.al. (2018) shows that labor market factors and opportunity costs influence the intention of students to become professional accountants.Based on the explanation above, the researcher will reexamine some factors that influence someone in choosing accountant or non accountant careers. Researchers decided to conduct research by the title "Surabaya City Workers, Why Choose Accountant Careers?".

\section{Literature Review}

According to Greenhaus, cited by Jusuf (2011), there are two approaches to understanding the meaning of career, as follows: the first approach views careers as ownership (a property) of occupation or organization. (Sulistyawati, 2013). This approach views career as a path of mobility in a single organization. The second 
approach views career as a property or individual quality. This approach views that career is a change in values, attitudes and motivations that occur in each individual. (Dary et.al, 2017), (Senjari et.al, 2016), (Srirejeki et.al., 2019). According to Snyder, cited by Carr (2004) stated that hope is the ability to plan a way out in an effort to achieve goals despite obstacles and make motivation as a way of achieving goals. (Yanti et.al. 2014), (Suyono, 2014), (Putra, 2011), (Cahyadi et.al., 2019)

According to Maslow, quoted by Feist Jess \& Feist Gregory (2010) stated that there are five levels of needs, namely:Physiological needs are needs that have priority in the Maslow hierarchy, so someone who has not met other basic needs will first meet their physiological needs, Safety and Security Needs are needs that need to identify the types of threats that can be harmful to humans, The need for love is a need after someone meets the physiological and security needs, they become motivated by the need for love, SelfEsteem Needs is a need that has two components, namely: a) self-respect is the need for knowledge about himself, that he is worth being able to master the tasks and challenges of life, b) get the rewards from others is the need for appreciation from others, fame domination, being important, respect and appreciation, The Need for Self-Actualization is the need to gain satisfaction with oneself, to realize all of his potential, to be whatever he can do it and to be creative and free to reach the peak of his potential achievements. (Mulianto et.al., 2014), (Asmoro et.al., 2015), (Rudiansyah et.al., 2017)

Factors to be considered in Choosing an Accountant or Non-Accountant Career. In this study, researchers took several factors from previous researchers into consideration in choosing a career accountant or nonaccountant (Rahayu, et.al., 2003), namely : Financial Awards (Salary)Earnings are the results obtained as an appreciation for the work that is fundamentally believed from most companies as the main attraction to provide satisfaction for employees, Professional Recognitionis an award in the form of non-financial related to recognition of achievement, Social value is the view of society towards the chosen career. (Setianto et.al., 2017)

According to the International Federation of Accountants in Yusran (2017), the accountant profession is all occupations that use expertise in accounting, including the fields of public accountants, internal accountants (companies), government accountants and accountants as educators.(Yendrawati, 2007), (Sari, 2013), (Susanti et.al., 2019)

\section{Research Methods}

This study uses survey methods with quantitative data to find out why choosing an accountant's career. The population of this study is workers who are in the city of Surabaya, this is based on the objectives and objects of research conducted by researchers. While the sample of this research is workers who take accounting courses in the city of Surabaya. Determine the number of samples in this study using calculations put forward by Roscoe quoted by Sugiyono (2017).

This research uses Structural Equation Modeling (SEM) is an analysis technique that allows testing a series of relationships simultaneously. This relationship is built between one or several independent variables with one or several dependent variables. SEM is an integrated approach between two analyzes namely factor and path analysis. The software used in this study is AMOS. Checking on the questionnaire data is tabulated to be directly inputted into AMOS (Noor, 2015).

Confirmatory Factor Analysis or CFA serves to identify indicators whether the indicators are extracted from research variables or indicators as a unit in other words have uni-dimensionl. CFA test was performed on each variable (Sarwono et.al. 2012).

\section{Results}

The following are the results of the CFA analysis in this study: 


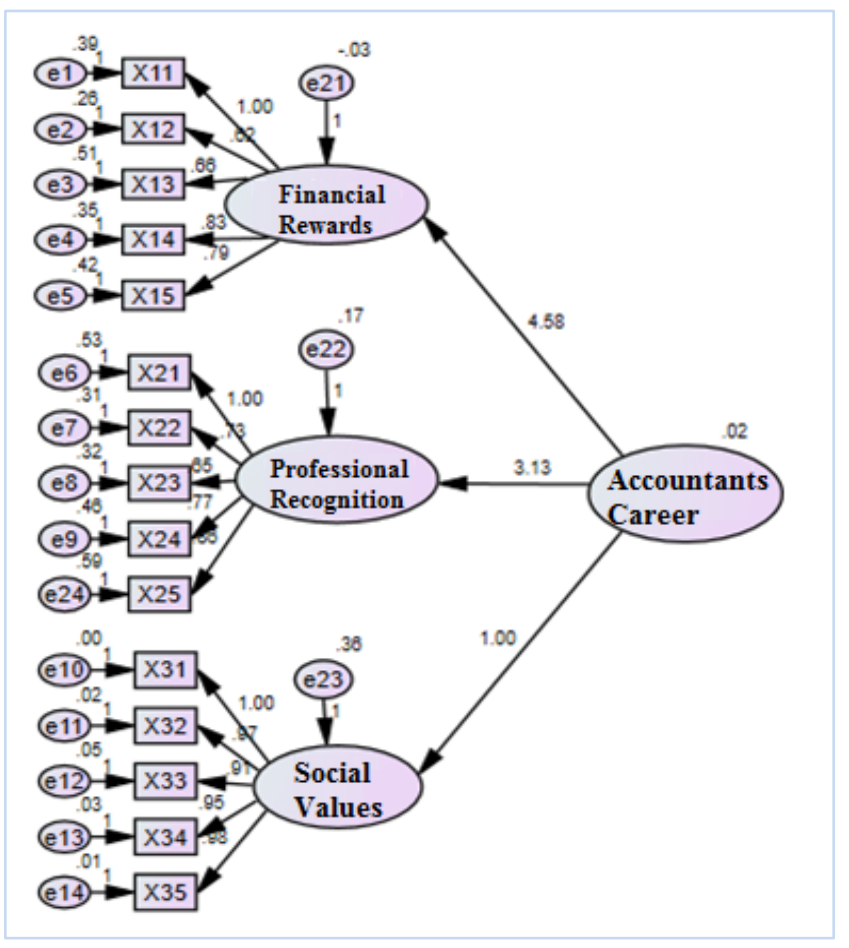

Source: Processed Data

Figure 1. CFA Analysis Results

As shown above, the chi-square value of 135,544 with $p=0.081$ can be seen that the $p$ value above the significance value ( $p>0.05$ ) indicates that there is no significant difference between the covariance of the sample and the population. A GFI value of 0.992 and AGFI of 0.950 indicates the recommended values above (>0.90). A df value of 1.558 indicates a value below that suggested $(<2.00)$, then an RMSEA value of 0.059 indicates a value below that suggested $(<0.08)$. A TLI value of 0.971 indicates the recommended value above (>0.95) so that the results of the CFA analysis meet the requirements, thus the model can be accepted marginally.

The test results in this study showed a significant and positive relationship between financial rewards (RW value $=4,583)$, professional recognition $(\mathrm{RW}$ value $=3,131)$, social value $(\mathrm{RW}$ Value $=1,000)$ and accountant's career. Referring to the results of Regression Weights (RW) shows that financial reward is an important factor for workers to undergo a career. The high value of financial rewards between professional recognition and social value is expected to attract workers or prospective workers to be positive about the accountant's career. This positive and significant test supports previous researchers conducted by Yusran (2017). The results in his research indicate that the factor of financial rewards, and professional recognition influences the career selection of accountants / non-accountants. Umar (2014) results in his research showed that there is a relationship between personal interests, salary and career choices of accountants among Nigerian University students. Djuri, Said and Amiruddin (2019) results in his research showed that lifestyle, and money-oriented influence on the choice of the accounting profession. Arnita, et.al. (2018) results in his research showed that opportunity costs affect the intention of students to become professional accountants.

\section{Conclusion}

In this study, it can be concluded that a person who graduates with his educational choice will definitely find a job. Someone who already has a job will try to get a good and better one. Existing profession in the field of accounting is indeed very promising, because accounting exists in all companies (services, trade and industry). Accounting is the language of business, large and small companies that run businesses will need accounting as the administrative wheel of the company. In this study the results of the analysis of the factors formed by 3 variables used as factors in the selection of accountants' careers are financial rewards, professional recognition and social values. The factor that shows the dominant value in choosing an accountant's career is financial rewards. 
[1] Ardianto, Elvinaro, 2014, Research Methodology for Quantitative and Qualitative Public Relations, Bandung, Simbiosa Rekatama Media.

[2] Carr, Alan, 2004, Positive Psychology: The Science of Happiness and Human Strength, New York, Brunner Routledge.

[3] Feist, Jess, Gregory J. Feist, 2010, Personality Theory, Jakarta, Selemba Humanika.

[4] Noor, Juliansyah, 2017, Research Methodology: Thesis, Thesis, Dissertation, and Scientific Work, Jakarta, Kencana.

[5] Sarwono, Jonathan and Budiono, Herlina, 2012, Applied Statistics: Applications for Thesis, Thesis, and Dissertation Research Using SPSS, AMOS, and Excel, Jakarta, PT. Elex Media Komputindo.

[6] Sugiyono, 2017, Quantitative, Qualitative, and R\&D Research Methods, Bandung, CV. Alfabeta.

\section{Journal entry}

[1] Arnita, Vina, Siti Rohaida, Mohamed Zainal, Dayana, Jalaludin, 2018, To Be or Not To Be? The Influencing Factors Towards Pursuing as Professional Accountant Among Indonesian S1 Accounting Students, International Academic Institute for Science and Engineering, Vol.5, No.3, page $1-10$.

[2] Asmoro, Tri K.W., Anita W. And Suhendro, 2015, Determinants of Career Selection as a public accountant by accounting students, journal of business and accounting dynamics (JDAB), Vol.2, No.2, P.123-135.

[3] Cahyadi, DD, Sari A. And Diah HS, Accounting Students Perceptions on Factors Affecting Career Choices (Study at Perbanas Surabaya STIE), Journal of Accounting and Strategic Finance (JASF), Vol.2, No.2, November, P.170 -182.

[4] Dary, A.W and Fitriwati I, 2017, The Effect of Gender, Financial Awards and Job Market Considerations on Accounting Students' Interest in Career Becoming a Public Accountant and Non-Public Accountant, Accounting Journal Vol.7, No.1, February, Pp.51-60.

[5] Djuri, Phatra A., Darwis Said, Amiruddin, 2019, The Effect of Lifestyle, Work Environment and Career Path of Accounting Bachelor on the Selection of Accounting Profession with Money Oriented as Moderting Variables, International Journal of Academic Research in Accounting, Finance and Management Sciences, Vol.9, No.1, January, page 80-93.

[6] Jusuf, Irianto, 2011, Management of Human Resources in the Public Sector in Indonesia: Introduction to the Development of the Public Sector HRM Model ". Journal of the Department of Administration, State Administration Study Program, FISIP, Airlangga University, Vol.24, No.4, P.281-291. [13] Mulianto, S.F and Yenni M., 2014, Factors Influencing the Career Choices of Accounting Students as Tax Consultants, Tax \& Accounting Review, Vol.4, No.2, pp.1-14.

[7] Putra, W.E., 2011, Analysis of the Difference in the reception of jambi university accounting students regarding the factors influencing career selection, Journal of Investment, Vol.7, No.1, Juni, pp.1-13.

[8] Rahayu, Sri, et al, 2003, Accounting Student Perceptions Regarding Factors Affecting Career Selection, SNA VI, Pg. 821-837.

[9] Rudiansyah, Y., and Lilis Y., 2017, Factors influencing career selection to become a public accountant, Journal of Accounting Science and Research, Vol.6, No.9, Pp.1-22.

[10] Sari, M., 2013, Factors Influencing Career Choices to Become a Public Accountant by Students of the Accounting Department of the Faculty of Economics of UMSU Medan, Journal of Accounting and Business Research, Vol.13, No.2, September, Pp.174-201.

[11] Senjari, R, Amir H. And Azhari S., 2016, The Effect of Motivation, Work Environment and Social Values on Accounting Student Interest in Choosing Career as a Public Accountant, JOM FEKON Vol.3, No.1, February, Pp.133-147.

[12] Setianto, A.I., and Yusri A.H., 2017, Factors Affecting the Interests of Accounting Student Study Program Selection Career Public Accountans, Journal of Applied Managerial Accounting, Vol.1, No.1, March, Pp. 51-61. 
[13] Srirejeki, K., Saras S. and Agus F., 2019, Understanding The Intentions Of Accounting Students To Pursue Career S A Professional Accountant, Binus Business Review, Vol.10, No.1, March, Pp. 11-19.

[14] Sulistyawati, A.I., Nina E. And Netty S., 2013, Perspectives of Accounting Students Regarding Factors Affecting Career Selection, Journal of Accounting Dynamics (JDA) Vol.5, No.2, September, Pp.86-98.

[15] Susanti, M., Sofia P.D. and Sufiyati, 2019, Factors Affecting The Selection Of Student Careers As A Public Accountant, Journal of Accounting, Vol. 23, No.2, May, Pp.269-284.

[16] Suyono, A.A., 2014, Analysis of Factors Affecting Career Selection as a Public Accountant (Empirical Study of UNSIQ Accounting Students), PPKM II Journal, Pp. 69-83.

[17] Umar, Ibrahim, 2014, Factors Influencing Students' Career Choice in Accounting: The Case of Yobe State University, Research Journal of Finance and Accounting, Vol.5, No.17, pages 59-62.

[18] Yanti N., Vince R. And Supriono, 2014, Analysis of Factors Affecting Accounting Students in Career Selection to be a Public Accountant (empirical study at PTN and PTS in Pekanbaru), JOM FEKON Vol.1, No.2, October, Pp . 1-15.

[19] Yendrawati, Reni, 2007, Perceptions of Accounting Students and Students Regarding Factors Affecting Career Selection as an Accountant, Journal of Phenomenon Vol.5, No.2, September, Pp. 176-191.

[20] Yusran, Rio Rahmat, 2017, Analysis of Factors Affecting Student Interest in Accountant / NonAccountant Career Selection, Journal of Accounting, Vol.5, No.2, April, pp. 203-212. 